\title{
A Comparative Study on Achievement Motivation of Children of Employed and Non-Employed Mothers
}

\author{
ASL Sowmya ${ }^{1}$, Dr. E. Manjuvani ${ }^{2}$ \\ ${ }^{1}$ Teaching Associate, Department of HDFS, C.H.Sc, Hyderabad, India \\ ${ }^{2}$ Professor, Department of HDFS, SPMVV, Tirupati, India
}

\begin{abstract}
The present study aims to study whether the achievement motivation of children of employed mothers differ significantly from children of non-employed mothers. The study further compared the achievement motivation of children of employed and nonemployed mothers on the basis of gender. The total sample for the study comprised 200 students selected randomly from $8^{\text {th }} 9^{\text {th }}$ and $10^{\text {th }}$ classes of different schools of Tirupati, Andhra Pradesh. The final sample consisted of 100 children of employed mothers and 100 children of non-employed mothers with equal distribution of 50 boys of employed mothers, 50 girls of employed mothers, 50 boys of nonemployed mothers and 50 girls of non-employed mothers. Deo-Mohan Achievement Motivation Scale (DAMS) developed by Deo and Mohan was administered to the selected sample to assess their achievement motivation. The obtained data were analyzed by mean, SD and t-test. Analysis of the results revealed that children of employed mothers had higher achievement motivation compared to the children of non-employed mothers. Further findings indicated that adolescent girls scored higher on achievement motivation compared to adolescent boys.
\end{abstract}

Keywords: Achievement Motivation, Employed mothers and Non-employed mothers, Adolescent boys and adolescent girls

\section{Introduction}

In recent years owing to spread of education, search of the identity and introduction of technological changes, increasingly large number of women in India are entering the job market. Rapid expansion in women"s education in the post independence period has improved the possibility of their employment. Today there is no profession which women have not entered.

According to 2011 census in India, there were 149 million female workers as against to the female population of 587 million. Women"s work is not only a means of effective economy and raising the standard of living of the people, it derives a sense of satisfaction in being considered valued members of the society (Anuradha Sharma, 1999). Higher levels of female entrepreneurial activity in turn have been associated with stronger economic growth. Indeed, EsteveVolart (2004) uses panel data on Indian states to show that the ratio of female to male workers (and managers) is positively correlated with both growth and living standards. There are also provisions for facilities such as childcare at worksites, so as to reduce the barriers to womens" participation (Government of India, 2014).

A mother is particularly important not because she has special skills but because she is with her children for a much greater time than any other person and her instructions reflects a very strong influence on attitudes, abilities and behaviour of children. Most of those children who are successful and well-adjusted come from homes where parental attitudes are favorable and a wholesome relationship existed between children and parents (Priyanka Aeri and Devina Jain 2010). According to Lyn Crage (2006), those mothers who are high educated and working are more sensitive to their children.
Mancini and Pasqua (2012) have studied on mothers' actual time spending with their children. Results shown that working mothers, with respect to non-working ones, tend to reduce the "basic care" time, but not "quality care" time devoted to their children (reading stories or helping them with homework, taking their children to a museum or to theatre). Therefore, even if working, they may be able not to reduce the time devoted to activities which are more likely to positively influence the school results of their children. Saini (2005) conducted a study on family environment and academic achievement of children of working and nonworking mothers. Major findings of the study revealed that children of working mothers were more independent than children of non-working mothers and children of working mothers were higher in academic score than those of the children of non-working mothers.

Linnenbrink and Pintrich (2002) examined research pertaining to student motivation and four key components that included academic self-efficacy, attributions, intrinsic motivation, and achievement goals. Males and females were found to have different competence-related beliefs during childhood and adolescence (Wigfield \& Eccles, 2002). Results revealed that boys had higher competence beliefs in sports activities and math compared to girls. However, girls had higher competence beliefs in reading, English, and social activities compared to boys. Linnenbrink and Pintrich posited that competence beliefs are important because they predict performance and task choice. These beliefs also affect the student"s motivation to succeed and achieve a goal. Other researchers have investigated gender differences in future orientation and motivation (Greene \& DeBacker, 2004). This meta-analysis examined differences in orientation and motivation across several studies. They concluded that females typically pursue a greater array of goals compared to males. 


\section{International Journal of Science and Research (IJSR) \\ ISSN (Online): 2319-7064}

Index Copernicus Value (2013): 6.14 | Impact Factor (2014): 5.611

\section{Objectives}

1) To compare the achievement motivation of children of employed and non-employed mothers.

2) To compare the achievement motivation of sons of employed and non-employed mothers.

3) To compare the achievement motivation of daughters of employed and non-employed mothers.

4) To compare the achievement motivation of sons and daughters of employed mothers.

5) To compare the achievement motivation of adolescent boys and girls.

\section{Hypotheses}

1) There would be no significant difference in achievement motivation of children of employed and non-employed mothers.

2) There would be no significant difference in achievement motivation of sons of employed and non-employed mothers.

3) There would be no significant difference in achievement motivation of daughters of employed and non-employed mothers.

4) There would be no significant difference in achievement motivation of sons and daughters of employed mothers.

5) There would be no significant difference in achievement motivation of adolescent boys and girls.

\section{Sample of the Study}

Table 2: Means, SDs ${ }^{\text {ee }}$ and ,te ${ }^{\text {ee }}$ values of children of employed and non-employed mothers on achievement motivation

\begin{tabular}{|c|c|c|c|c|c|c|c|}
\hline \multirow{3}{*}{$\begin{array}{c}\text { Achievement } \\
\text { Motivation }\end{array}$} & \multicolumn{2}{|c|}{$\begin{array}{c}\text { Children of Employed mothers } \\
(\mathrm{n}=100)\end{array}$} & $\begin{array}{c}\text { Children of non-employed mothers } \\
(\mathrm{n}=100)\end{array}$ & \multirow{2}{*}{ "t"value } & „pe value & Level of significance \\
\cline { 2 - 9 } & Mean & SD & Mean & SD & & & \\
\cline { 2 - 9 } & 198.67 & 18.00 & 192.32 & 17.26 & 2.546 & 0.012 & $*$ \\
\hline
\end{tabular}

* Significant at 0.05 level

Table 2 shows that there are significant differences between the children of employed and non-employed mothers regarding their achievement motivation as the obtained tvalue (2.546) is significant at 0.05 level. The Mean values of the children of employed and non-employed mothers on the achievement motivation are 198.67 and 192.32 respectively. It reveals that the children of employed mothers are having
The total sample for the study comprised 200 students selected randomly from $8^{\text {th }}, 9^{\text {th }}$ and $10^{\text {th }}$ classes of different schools of constituted population of Tirupati. The final sample consisted of 100 children of employed mothers and 100 children of non-employed mothers.

Table 1: Sex wise distribution of the sample

\begin{tabular}{|c|c|c|c|}
\hline \multicolumn{2}{|c|}{ Employed mothers } & \multicolumn{2}{c|}{ Non-employed mothers } \\
\hline Boys & Girls & Boys & Girls \\
\hline 50 & 50 & 50 & 50 \\
\hline \multicolumn{2}{|c|}{ Total $=100$} & \multicolumn{2}{c|}{ Total $=100$} \\
\hline
\end{tabular}

\section{Tool}

Deo-Mohan Achievement Motivation Scale (DAMS) developed by Deo and Mohan (1985) was used to measure the achievement motivation of the students.

\section{Data Collection}

The tool was administered on the selected students of $8^{\text {th }}, 9^{\text {th }}$, and $10^{\text {th }}$ standards in secondary schools. The scale was pretested on children to check the understandability of the items. The data for the present research was collected personally by the investigator from different schools included in the sample.

\section{Data Analysis and Interpretation}

The response received was analyzed through statistical applications using mean, Standard Deviation and t-test to test different hypotheses.

Table 3: Means, SDs ${ }^{\text {ee }}$ and ,tee values of Sons of employed and non-employed mothers on achievement motivation

\begin{tabular}{|c|c|c|c|c|c|c|c|}
\hline \multirow{3}{*}{$\begin{array}{l}\text { Achievement } \\
\text { Motivation }\end{array}$} & \multicolumn{2}{|c|}{$\begin{array}{l}\text { Sons of Employed mothers } \\
\qquad(\mathrm{n}=50)\end{array}$} & \multicolumn{2}{|c|}{$\begin{array}{l}\text { Sons of non-employed mothers } \\
\qquad(\mathrm{n}=50)\end{array}$} & \multirow[t]{2}{*}{ „t"value } & \multirow[t]{2}{*}{,p palue } & \multirow{2}{*}{$\begin{array}{l}\text { Level of } \\
\text { significance }\end{array}$} \\
\hline & Mean & SD & Mean & SD & & & \\
\hline & 193.72 & 19.46 & 191.76 & 17.00 & 0.536 & 0.593 & @ \\
\hline
\end{tabular}

(a) Not Significant

Table 3 shows that sons of employed and non-employed mothers did not differ significantly. The obtained t-value is 0.536 and the Mean values of sons of employed mothers is 193.72 and sons of non-employed mothers is 191.76 respectively. It reveals that the second hypotheses "There high achievement motivation than the children of nonemployed mothers. Hence it leads to rejection of the first hypotheses i.e. "There would be no significant difference in achievement motivation of children of employed and nonemployed mothers". 


\section{International Journal of Science and Research (IJSR) \\ ISSN (Online): 2319-7064}

Index Copernicus Value (2013): 6.14 | Impact Factor (2014): 5.611

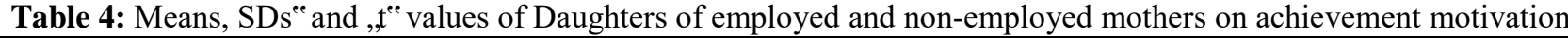

\begin{tabular}{|c|c|c|c|c|c|c|c|}
\hline \multirow{3}{*}{$\begin{array}{l}\text { Achievement } \\
\text { Motivation }\end{array}$} & \multicolumn{2}{|c|}{$\begin{array}{l}\text { Daughters of Employed mothers } \\
\qquad(\mathrm{n}=50)\end{array}$} & \multicolumn{2}{|c|}{$\begin{array}{l}\text { Daughters of non-employed mothers } \\
\qquad(\mathrm{n}=50)\end{array}$} & \multirow[t]{2}{*}{ „t, value } & \multirow{2}{*}{$\begin{array}{l}\text { „pe } \\
\text { value }\end{array}$} & \multirow{2}{*}{$\begin{array}{l}\text { Level of } \\
\text { significance }\end{array}$} \\
\hline & Mean & SD & Mean & SD & & & \\
\hline & 203.62 & 15.04 & 192.88 & 17.67 & 3.273 & 0.001 & $* *$ \\
\hline
\end{tabular}

** Significant at 0.01 level

Table 4 indicates that daughters of employed and nonemployed mothers differ significantly at 0.01 level on achievement motivation. Daughters of employed mothers scored higher on achievement motivation compared to the daughters of non-employed mothers. The obtained t-value (3.273) is significant at 0.01 level. The mean values of the daughters of employed and non-employed mothers on the achievement motivation are 203.62 and 192.88 respectively. So it leads to rejection of the third hypotheses i.e. "There would be no significant difference in achievement motivation of daughters of employed and non-employed mothers".

Table 5: Means, SDs"e and ,t" values of Sons and Daughters of employed mothers on achievement motivation

\begin{tabular}{|c|c|c|c|c|c|c|c|}
\hline \multirow{3}{*}{$\begin{array}{l}\text { Achievement } \\
\text { Motivation }\end{array}$} & \multicolumn{2}{|c|}{$\begin{array}{l}\text { Sons of Employed mothers } \\
\qquad(\mathrm{n}=50)\end{array}$} & \multicolumn{2}{|c|}{$\begin{array}{l}\text { Daughters of employed mothers } \\
\qquad(\mathrm{n}=50)\end{array}$} & \multirow{2}{*}{ „tevalue } & \multirow{2}{*}{ „p palue } & \multirow{2}{*}{$\begin{array}{l}\text { Level of } \\
\text { significance }\end{array}$} \\
\hline & Mean & SD & Mean & SD & & & \\
\hline & 193.72 & 19.46 & 203.62 & 15.04 & 2.84 & 0.05 & ** \\
\hline
\end{tabular}

** Significant at 0.01 level

Table 5 shows that there are significant differences between sons and daughters of employed mothers regarding their achievement motivation as the obtained t-value (2.84) is significant at 0.01 level. The Mean values of sons and daughters of employed mothers on the achievement motivation are 193.72 and 203.62 respectively. It reveals that the daughters of employed mothers scored higher achievement motivation compared to the sons of employed mothers. Hence it leads to rejection of the fourth hypotheses i.e. "There would be no significant difference in achievement motivation of sons and daughters of employed mothers".

Table 6: Means, SDs ${ }^{\text {ee }}$ and ,t, ${ }^{\text {ee }}$ values of adolescent Boys and Girls

\begin{tabular}{|c|c|c|c|c|c|c|}
\hline \multirow{2}{*}{$\begin{array}{c}\text { Achievement } \\
\text { Motivation }\end{array}$} & $\begin{array}{c}\text { Gender } \\
(\mathrm{n}=100)\end{array}$ & Mean & SD & $\begin{array}{c}\text { "tc } \\
\text { value }\end{array}$ & $\begin{array}{c}\text { "pe } \\
\text { value }\end{array}$ & $\begin{array}{c}\text { Level of } \\
\text { significance }\end{array}$ \\
\cline { 2 - 7 } & Boys & 192.74 & 18.20 & 2.20 & \multirow{2}{*}{0.02} & $*$ \\
\cline { 2 - 7 } & Girls & 198.25 & 17.19 & 2.20 & & \\
\hline
\end{tabular}

* Significant at 0.05 level

Table 6 shows that adolescent boys and girls differ significantly at 0.05 level on achievement motivation. Adolescent girls scored higher on achievement motivation compared to the adolescent boys. The obtained t-value (2.20) is significant at 0.05 level and the Mean value of adolescent girls is 198.25 and adolescent boys is 192.74 respectively. Hence it leads to the rejection of the fifth hypotheses i.e. "There would be no significant difference in achievement motivation of adolescent boys and girls".

\section{Conclusion}

1) The findings clearly indicated that maternal employment had positive impact on achievement motivation of the children.

2) Children of employed mothers had higher achievement motivation compared to the children of non-employed mothers.

3) There is no significant difference found in sons of employed and non-employed mothers.
4) Daughters of employed mothers scored higher on achievement motivation compared to the daughters of non-employed mothers.

5) Daughters of employed mothers found better than the sons of employed mothers on achievement motivation.

6) Adolescent girls scored higher on achievement motivation compared to adolescent boys.

\section{References}

[1] Anuradha,S. (1999). Women and Work: Human Resource Management Perspective. New Delhi: Pyan Publishing House.

[2] Census (2011) Women Employment: http://labourbureau.nic.in/Statistical_Profile_2012_13.p df

[3] Esteve-Volart. B. (2004). "Gender Discrimination and Growth: Theory and Evidence from India," STICERD Development Economics Papers 42, Suntory and Toyota International Centres for Economics and Related Disciplines, London School of Economics.

[4] Government of India, 2014, "Mahatma Gandhi National Rural Employment Guarantee Scheme: Report to the People", Ministry of Rural Development, New Delhi: Government of India.

[5] Greene, B. A. \& DeBacker, T. K. (2004). Gender and orientations toward the future: Links to motivation. Educational Psychology Review, 16 (2), p. 91-120.

[6] Linnenbrink, E. A. \& Pintrich, P. R. (2002). Motivation as an enabler for academic success. School Psychology Review, 31, p. 313-327.

[7] Lyn Crage. (2006). "Parental education, time in paid work and time with children" British Journal of Sociology 57(4) (C) London School of Economics and Political Science 200.

[8] Mancini, A.L., \& Pasqua, S. (2012). Asymmetries and Interdependencies in Time Use Between Italian Parents. Applied Economics, 44(32), 4153-4171.

[9] Priyanka Aeri and Devina Jain (2010). Effect of Employment Status of Mothers on Conceptual Skills of

\section{Volume 4 Issue 11, November 2015}




\section{International Journal of Science and Research (IJSR) \\ ISSN (Online): 2319-7064}

Index Copernicus Value (2013): 6.14 | Impact Factor (2014): 5.611

Preschoolers, Department of Human Development, Guru Nanak Girls College, Yamuna Nagar, Haryana, India (C) Kamla-Raj 2010 J Soc Sci, 24(3): 213-215 (2010).

[10] Saini, S. (2005). Family Environment and Academic Achievement of Adolescent Children of Working and Non-Working Mothers. Indian Educational Review,41(2),87-95

[11] Wigfield, A., \& Eccles, J. S. (2002). Development of achievement motivation. San Diego, CA: Academic Press. 